Ben

Woodard

\title{
Plotting Nature's Havoc: \\ Potential Realisms between Transcendental Materialism and Transcendental Dynamism
}

\section{Introduction}

This text attempts to address how the transcendental relates to the material (whether via realism or materialism) comparatively between (and across) Deleuze's transcendental materialism, Nick Land's commentary on transcendental synthesis and Iain Grant's nascent Schellingian transcendental dynamism. Whereas transcendence and the transcendental have traditionally been thought as hovering high above reality, in the thinkers above the transcendental is a kind of movement within the material though, admittedly, the very presence of transcendence then questions the usefulness of the term materialism vis-a-vis the term realism as well as transcendence vis-a-vis immanence. Or put otherwise, in the above fields transcendence seems to operate within immanence thereby complicating and perforating the boundary between realism and materialism.

If thinking is to grasp being without over-determining it (as a realism), it seems necessary to materialize the transcendental and render the dynamic un-prethinkable yet productive of thought. Yet, these acts cause an apparent de-realization of the material (if it bears the capacity of transcendence and not immanence), a intellection of nature that synthesizes (bordering on panpsychism) as well as a unknowability that threatens to sabotage the applicability of theory in practice.

Ultimately, I wish to argue that the problem of transcendence vis-a-vis immanence, speaks to the necessity of regionalizing metaphysics and grounding transcendence as the ontological shift between Transcendental Materialism, and Transcendental Dynamism within those registers or stages. Deleuze's (and Land's) Transcendental Materialism begins from the regime of sense and excavates the material which is cemented in the immanent whereas Iain Grant's Schellingian Transcendental Dynamism attempts to adhere to the progression of stages (or Stufenfolge in Schelling's parlance) as transcendence itself, which, in the real, is deduced as a series of potencies or powers.

Or, to put it yet another way, transcendence in transcendental materialism transcendentalizes sense into intensity, in 
transcendental realism transcendence transcendentalizies cognition into reason, and in transcendental dynamism, transcendence transcendentalizies the progression of nature into metaphysical progression. ${ }^{1}$

I will begin by exploring Deleuze's materialism by way of Brassier's critique of it. Following this I will show how Nick Land expands on Deleuze's materialism and shows its radical difference from Kant through Lands critique of the critical project. Finally, I will outline Iain Grant's Schellingian Transcendental Dynamism and how it differs from Deleuze and Land's uses of materialism and the transcendental.

\section{Brassier and Deleuze or Transcendental Immanence to Transcendental Materialism}

The expansive work of Deleuze is a theoretical delirium, a materialist carnival that dabbles in philosophy, the sciences, literature, aesthetics and other realms. Because of Deleuze's wide range yet enigmatic insistence that he was a "pure-metaphysician," the degree to which his materialism is material is easily obfuscated. Yet several attempts have been made to make Deleuze into a realist.

Deleuze (and Guattari) are thinkers of the horizontal, the plane, the rhizomatic, of lines of flight. Their materialism is an expansive horizon, but a materialism imbued with an ideal glow as this strange world, in its broad view, is thinkable. This thinkability is not due to apperception or to Kantian transcendental categories, nor to post-Kantian intuition, nor objective or pragmatic grasp of the world via the powers of reason, but a formulation of phenomenologized sense in which materiality and the productivity of that materiality is the work of a machinic unconscious. Deleuze's philosophy is the expansive self-churning of thought which is at worst, in François Laruelle's terms, philosophy playing with itself but, at its best, a radical empiricism conscious of its realist limits. (Laruelle 2009, 163-164)

François Laruelle's condemnation of Deleuze is that of philosophy on the whole and its use of transcendental synthesis, its mental characterization of the real (and reality) that is then worked on with the instruments of philosophy as if these entities, or packets of data, were not already made philosophizable. Deleuze becomes the bearer of all of philosophy's over-determining and overreaching talons.

Laruelle's as well as Ray Brassier's critique of Deleuze, can be read against various realist readings of Deleuze, where for the former Deleuze's thought is self-sealed storm of thoughts for the latter Deleuze's articulation of empiricism and sense points to the limits of thought. Or, put another way, Deleuze can be seen as being too out of this world for his realist critics where for De Landa and others Deleuze merely indexes the other worldliness of the world (namely the virtual for De Landa) the ontologcal reservoirs which make change, individuation, becoming, and so forth.

The two intertwined issues become the knowability/ sensibility of the ontological unknowns as well as the 
ontological status of knowing and sense. The crux of this relation is that of transcendental materialism, and of those terms in relation to one another as well as sense and knowing all of which are frequently couched within representation. These terms are, of course, all too broad to fully flesh out in one go, but the attempt will be made to show how the communication and connectivity between them is particular to Deleuze's philosophical work.

As Ray Brassier puts it "as far as the empirical realm is concerned, the business of a genuinely critical transcendentalism lies in articulating real conditions of ontological actuality rather than ideal conditions of epistemological possibility." (Brassier 2001, 54) Brassier goes on to say that the transcendental, for Deleuze, is a methodological flattening of subject and object whereby the transcendental is immanentized.

It is here we circle back to the thoughtful horizontals previously mentioned as the opera of Deleuzian work. Deleuze's horizontality is accomplished chiefly by placing the transcendental below ground in order for it to expand rhizomatically sideways. This planting is supplanted by Deleuze, again following Brassier, in Deleuze's attack on the transcendental as from the I (or subject, or thinker, or from consciousness) immediately atomizes the processes and powers attributed to that subject thereby eroding the efficacy of representation. (ibid., 55) Deleuze's "circumvention of the first person phenomenological perspective," Brassier argues, "effectively explodes the very kernel of subjectivity, subverting it as its originary root by dismantling the principle of ontological individuation through which it is constituted." (ibid., 56) Deleuze's atomization of the transcendental has, as we've already suggested in passing via De Landa, of opening up the sub-representational or pre-individual. Again, following Brassier: "This pre-individual, impersonal transcendental field sought for by Deleuze constitutes the empirically inexhaustible realm of virtual singularities" which are nomadicially (ibid., 57-58) distributed.

This wide field of transcendental immanence means, in relation to our privileged terms of knowing and sense, that the real becomes a philosophical singularity (ibid., 58) as a means of the real to think itself. (ibid., 59) The philosophical singularity then maps the unpresentable reservoirs via an altogether different sense of sensibility provided by the great smashing of the world into ontological univocity. Continuing through Brassier's critique, it is the disjunction of difference and repetition which keeps representation at bay while allowing for breaks between various singularities, between what is thinking and what is being thought (ibid., 60) but this difference presupposes the presupposition of an unthinkability which is in thought itself. (ibid., 65)

It becomes necessary here to avoid the vertigo of terminology and return to the onto-epistemological scaffolding being deployed. The problem becomes if thought is self-productive, then the unthinkable is only a byproduct of the process of thought expanding outwards via the very process of thinking: "the unthinkable is at once absolute limit and ground of deterritorialization ... and pre-supposition which is internally posited as unthinkable exteriority via the self-positing of thought" (ibid..) which seems to simultaneously invoke qualitative differences between being and thinking while asserting their unity. While an obvious response would be that the being 
of the world is that very play of differences it seems difficult, if not impossible, to localize the genesis of thought given the havoc of horizontality.

Or, to dip into terminological vertigo, the defense of Deleuze's strafing, would be where the disjunction occurs between the virtual and the actual in the process of individuation occurring from the intensities within the broad plane of immanence. But since the process of individuation requires the actual and the virtual, both of which are within the plane of immanence, it becomes difficult to know, or sense, what the difference of actuality means in relation to knowing or sensing. To quote Brassier yet again:

individuation as sufficient reason for the virtual's self-actualisation inscribes a circuitous loop; a relative asymmetrical parallelism between virtual intensity and actual extensity; a reciprocal co-implication whereby every actual differentiation of the virtual immediately implies a co-responding virtual differentiation of the actual. (ibid., 69)

Thought is already there, as Laruelle warns against all philosophy, rising from the seed of its always already-ness, which is ultimately a "hyletic indiscernability" where there is possibility of discerning between anything and the processes which allow various forms of thingness. (ibid., 82)

Tying this problem to immanence Brassier states that "Deleuze insists, it is necessary to absolutize the immanence of this world in such a way as to dissolve the transcendent disjunction between things as we know them and as they are in themselves." (Brassier 2008,
3) That is, whereas Kant relied on the faculty of judgment to divide representation from objectivity (ibid., 2) Deleuze attempts to flatten the whole economy beneath the Juggernaut of univocity.

But given the pulverization of the difference between thought and being and the disabling of knowing, how is it that Deleuze justifies access to the world? Again, as Brassier shows, Deleuze reinvigorates the function of sense to magnify empiricism through the unbinding of the aesthetic dimension. (ibid., 17)

The ecstatic aesthetic binds several themes which will continue throughout this paper. Nick Land engages the relation between judgment and aesthetics (via the sublime) making this the jumping off point for diagnosing the limitations of Kant's structured reason yet, at the same time, it questions the limits of sense in Deleuze. That is, despite the more realist readings of Deleuze (De Landa) and the more phenomenological (Massumi) Deleuze's ontology relies problematically on the pseudo-physicalized empirical namely in terms of the concept of sense and, even more specifically, intensity. It is for this reason that while the terms here are not that of judgement, aesthetics, and the sublime, these terms lead into the limits of the transcendental.

Steven Shaviro in his text Without Criteria, explicitly links Deleuze and Kant in the following way: "Deleuze's own 'transcendental empiricism' centers on his notion of the virtual. I think that this much-disputed concept can be best understood in Kantian terms. The virtual is the transcendental condition of all experience" which utilizes Ideas as 
unpresentable but real, thereby avoiding both dogmatism and skepticism. As Shaviro argues however, there are substantial differences between Kant and Deleuze specifically the fact that Kant's transcendence is in the realm of the subjective whereas for Deleuze it is impersonal and presingular. (Shaviro 2009, 33-34) In an argument similar to Land, and summing up this relation, Shaviro concludes: "the virtual is entirely distinct from the possible. If anything, it is closer to Nietzsche's will-to-power, or Bergson's elan vital. All of these must be understood, not as inner essences, but as post-Kantian 'syntheses' of difference: transcendental conditions for dynamic becoming, rather than for static being." (ibid., 35)

The obvious, perhaps even silly question here, becomes how does an apparatus of sense that is becoming (whether human, non-human) senses becoming? While a common Kantian deflection is that critics of Kant misunderstand the role of the constitutive and the normative, it does not adequately explain how the normative structures Kant invokes came into being but merely dismisses such questions as operating with in a form of philosophy already always dismissed by Kant. This dismissal merely metastasizes the decisional (or correlational) structure of philosophy so that not only does the critical project think thinking as the only legitimate form of philosophy but also asserts that to attempt a break out of the circle isn't even philosophy yet later moves in Kant's own work (especially in the Opus Postumum) suggest that he yearned for some grounding of the speculative that was somehow non-structural.

Advocating for an ontology of becoming must then explain the genesis of the structural that is not purely thinkable. Given this problem it is perhaps unsurprising that one of Deleuze's most interesting commentators François Zourabichvili argues that there is no ontology of Deleuze, and that, one could argue, that Deleuze's philosophy is one of sense and not unsensible metaphysics. Given that, Brassier's response following from his critique of transcendental immanence and transcendental materialism outlined above, it is unsurprising that in Brassier's own project he seeks to exclude thought from materiality but not by given it ahistorical a priori forms but by binding it to nothing.

But what is unsatisfying here is the ground of thinking in relation to the status of material or materialism, and hence our interest in transcendence not as different in kind from immanence, of arching over materiality but being a modality of immanence and or ground. To this end we will engage Nick Land and Deleuze.

\section{Land and Deleuze or Transcendental Materialism to Transcendental Synthesis}

Nick Land's work has often been described as a hyper (or mad black) Deleuzianism given Land's nihilistic tendencies (as opposed to Deleuze's cloying positivity) and his, in a sense, Deleuzian attack on Deleuze himself. I do not wish to challenge this representation. Here, following the above remarks on Kant and Deleuze via the issue of sense, we will map how Land's utilization of sense and synthesis further problematizes the immanence-transcendence relation as it crosses the connection of thinking to being as was articulated above in Brassier's critique of Deleuze. 
Throughout the texts in Fanged Noumena, Land pulls the extra-philosophical from Kant (Land 2011, 6) as he is specifically interested in synthesis. (ibid., 7-9) Land argues that Kant's transcendental is "productive synthesis" as the transcendental is the eruption of synthesis from unknown materiality, from an intensive matter (ibid., 13). As Robin McKay and Ray Brassier put it in the introduction:

there is no real difference between synthesis as empirical conjunction at the level of experiences and synthesis as a priori conjunction of judgement and experience at the transcendental level. (ibid., 13-14)

Furthermore, Land critiques Kant for the concept of synthetic a priori knowledge (ibid., 64) which indexes a kind of unintentional excess (ibid., 70) and that transcendental thinking is only ever thinking about thinking (ibid., 92), which perhaps indexes Laruelle's critique of the decisional status of philosophy itself. Beyond this, Land argues that the sublime is one form of thinking that self exceeds as intuition (ibid., 135, 145) which he then argues speaks to being the very generation of reason and not its excess (ibid., 137) - the generative excess of the sublime, of specifically the dynamic sublime is subsumed under the experience of our vulnerability. (ibid., 138) "Thought is a function of the real, something that matter can do." (ibid., 322)

Land continues to lay into Kant for restricting faculties of thinking as it defangs nature when he writes: "Far from having been domesticated by the transcendental forms of understanding, nature was still a freely flowing wound that needed to be staunched" (ibid., 148) nature becomes a dangerous surplus of energy as material as it is libidinal (ibid., 151), it is unplanned synthesis. (ibid., 17, 313) Later on he continues:

Kantian transcendental philosophy critiques transcendental synthesis, which is to say: it egresses against structures which depend upon projecting productive relations beyond their zone of effectiveness. (ibid., 321)

On the one hand Land wishes to critique the audacity by which Kant attempts to override or disavow thought's grasp on non-thought but he doesn't want to disregard thought's capacity to be an active materialism, a dynamic materiality. It is difficult however to qualify this materiality in a positive sense beyond its constructivism though this constructivism can function as a positivization of a critique of the critique.

Because the fangedness or uninhibited nature of nature is not defined or further articulated Land's Schellingianism is under evolved although they both entertain a fractured absolutism. As Mackay and Brassier state in the introduction Land nominates his own project as Schellingian but develops a far more Deleuzian project. (ibid., 22) Put otherwise, Land (in an odd twist) forms a kind of urgrund of the project of Schelling's positive philosophy (critiquing both Kant and Hegel) by completing Schelling's transcendental Spinozism "in which the corrosive dynamic of critique ceases to be compromised by the interests of knowledge, but proceeds instead to fully absorb thought itself within the programme of a generalised ungrounding, now materialised and operationalised as destratification." (ibid., 28) 
Land's material codification of thought moves between Spinoza, Schelling and Deleuze, utilizing Schelling's dynamization of transcendence as well as Spinoza's substance falling into the intensive zero or body without organs functioning as the brain-dead engine of all failed identity. Thinking becomes a capacity of matter itself (ibid., 172, 188) while at the same time "Matter cannot be allowed a category without being certified for ideality." (ibid., 210) Land's materialism moves beyond all judgment while allowing all the turbulences of matter to serve as paths of exploration and not instances of inhibition or individuation. (ibid., 211)

The tension in Land is between the faulty utilization of philosophy as thinking itself versus the resultant materiality of thought becoming an expression of the material. That is, Land is critical of Kant's transcendental idealism yet it remains unclear how materialism relates to Kant's articulation of the transcendental vis-a-vis idealism and realism.

Land notes and privileges Schelling's critique of Kant's transcendental program (ibid., 263) and expresses the importance of the inhumanization of cognition (ibid., 293) opposed to transcendental philosophy as the consummation of judgment. (ibid., 300) Yet this machinic unconscious raises the problematic of whether or not the atomization of subjectivity which Brassier critiques in Land and Deleuze moves to far towards the phenomenological. (ibid., 303)

That is, while Land rightly critiques Kant for relying on trans-historical categories to suppress both nature and creative modes of thinking, kinds of thinking which leave themselves open to madness in Kant's eyes. Yet, a total eradication of systematization, or formalization, material or otherwise, complicates the structures of thought, whether thought and materiality can be differentiated.

While Schelling moves between mechanism and vitalism Land feverishly runs Deleuze and Guattari's machinic model where both arrive at a processual nature that chews and gnaws at formal solidity the difference between how both thinkers relate being and thinking given a flowing nature.

Land's strategy, borrowing from Brassier's critique, is the materialization of critique where for Schelling it is the atomization of intuition. Brassier argues that Land's philosophy is problematic since he eschews the necessity of a noetic fall back it becomes difficult or maybe impossible, to distinguish between thoughts and things a distinction imperative for any claim to realism.

This is further complicated by immanence in Land as a kind of non-divided energy. In The Thirst for Annihilation Land connects immanence to time (time being that which is necessary for Schelling to maintain a heterogeneity in his monism). "Time," Land writes, "is thus the ultimate ocean of immanence, from which nothing can separate itself, and in which everything loses itself irremediably." (Land 1991, 95) Further on Land writes: "transcendent matter loses the perfection of its inertia (design), and nature implodes into the spasms of its own laceration." (ibid., 96) 
The universe as time takes apart nature while nature infests time with materiality in various forms. Yet these forms then are original, they coexist with the very emergence of time bringing materiality back to zero intensity, a body without organs, a unit of materiality that seems only to self-present itself as an is-ness, or being, that is thinkable and intensive. It becomes difficult to determine the limits of Schelling's holistic monism versus Kantian monadic individualism as the two fall into the jaws of Land's relentless nature. The degrees of difference, in Land's case, are remanded to the domain of intensity but this brings up a host of other issues. Put another way the question becomes: Is there a tension between construction and the unplanned - that is, where there might be some rawness or unthinkability to synthesis for Land, sense is still sensible despite this chaotic ground. The categories of intensity question the ontological validity of sense (or the aesthetic or judgment or for that matter affect) in so far as they presuppose some sensitivity at least partially translatable into thought or the thinkable.

Or, to put it yet another way, in Deleuze the transcendence of transcendental materialism transcendentalizes sense into intensity, where Land tries to reverse the formula tracing the roots of various stratifications of intensity back to a sensing material which harbors a modal difference which can be read as transcendence in the Schellingian sense if not in the Kantian sense. Following this argument, Land would seem to fall more into the Spinozist camp where the heterogeneity of a materialism (whether that material is transcendent or libidinal) is caused by varying qualitative difference registered within that materiality and caused by that materiality. The clearest outline of this is expressed by Land in the following:
The thing is the instance of a petrified separation - a fetish - which represses both indistinct immanence and the difference from indifferentiation. This is because the immanence buried beneath the crust of things is the common but complex source of difference in (intensive gradations of) transcendence; the generative materiality in which everything real in transcendence must abysmally participate, and from which every separation or isolation must draw its force. (ibid., 196)

For Land transcendence is merely the differentiation of immanence - the mechanism by which nature stratifies itself, strata by which transcendence extends out unilaterally and horizontally. (ibid., 170) In this sense Land again sways toward German Idealism and Kant (particularly the later Kant). But whereas Land locates zero in a kind of Spinozistic substance Kant domesticates thought by turning it into pure consciousness. (ibid., 116) Again, Land circumvents this by appealing to sense since sense for Land, allows for one to detect the locality of an intensity. But, as has already been noted, despite transcendental materialism as self-differentiality, it becomes difficult if not impossible to register the difference between difference as due to reason and difference as ontological, or difference in itself.

As we will address in the next section, Schelling, in a proto-Deleuzian faction, practices a radical conception of unity (a monism beyond Spinoza because of the capacity of individual bodies within the realm of freedom) but only at the cost of difference-in-itself. The difficult relation of Deleuze and Schelling stumbles upon the possibility of heterogeneity within unity vis-a-vis the work of reason. In this, Land's transcendental materialism struggles with many of the same issues of Kant's somewhat mysterious 
use of the manifold and the problem of extensity in the Opus Postumum. The problem becomes that materiality is intensive yet some not material register (some separation or formalization) which for Deleuze and Land (and arguably Kant) is sense yet if Land wants to ground or horizontalize (or make rhizomatic) transcendence than materiality thinks and senses itself. Synthesis becomes auto-synthetic and there is no registerable difference between thought and non-thought only a self-determined meter of intensity, but this receptivity must be either fundamentally separated from materiality (as Kant does) or self-differentiation must make a difference that is simultaneously ontological and not.

This problem, I want to argue, leads one to dynamism and not materialism as materiality does not adequately address heterogeneity, a heterogeneity necessary which suggests, and is required by, any kind of realism however weird, heretical, or speculative that realism be.

\section{Deleuze and Schelling or Transcendental Synthesis to Transcendental Dynamism}

If Deleuze is an ontological astronaut (with Land pushing this towards the theoretical equivalent of Science Fiction Horror) then Schelling is surely an ontological archaeologist. Schelling is endlessly haunted by the past, by the time before the world, by the chaotic darkness, of nature as primal forces, of the absolute. As Christopher Groves points out, Deleuze's relationship to Schelling is half criticisms and half praises. Groves in "The Ecstasy of Reason" points out that Deleuze defends Schelling from
Hegel but also lambasts his absolute for not being able to properly maintain difference in itself.

It will be argued that Schelling's non-sense based (yet non-Kantian) usage of the transcendental as well as Schelling's dynamism (contra Deleuze's immanence and materialism) allows for a form of realism that Deleuze's philosophy does not.

Grant closes Philosophies of Nature after Schelling by examining the differences between Deleuze and Schelling specifically through the lens of dynamism as transcendental physics. (Grant 2006, 187) This physics is transcendental as it simultaneously explains the emergence of things while presupposing the unity of thought and matter that is, Schelling's transcendental physics is the method by which unity explains difference. (ibid., 188)

The central difference between Schelling and Deleuze is that for the former continuity is the possibility of difference whereas for the latter it is difference in itself, the former occurring through a self-fracturing identity. (ibid., 189) Key to this distinction is the fact that Schelling's utilization of the transcendental is a form of ontological regime change and not a marker of sensible intensity. Furthermore, Schelling's dynamism provides to be more useful than transcendental materialism simply because instead of receptivity and sense being separated in order to be barraged by intensive material, all things are shot through with force (ibid., 190) making them intuitable if not completely sensible. Grant sums up this difference in the following fashion: 
For Deleuze as for Schelling, limited objects are exceeded on both sides by the forces and actions of matter and Idea. What differs between the two accounts is on the one hand, the focus of the forces, and on the other, the nature of the Idea. Concerning the first, for Deleuze, the teeming subterranean multiplicity of becomings have as their antithesis the unshakable vertical radiance of the solar One, in a struggle over the determination of sensible bodies and the balance of powers between those exercised between them, and those exercised upon them. For Schelling, by contrast, the becoming of being consists in passages and transitions, while identity consists in potentiations and depotentiations, determining the limited thing as a power of the unlimited, while limited things are in turn "approximations of productivity." (ibid., 191)

The problem then swings to the original force, or central activity, or how dynamism relates to temporality, and to the problem of ground as it manifests in the relation of immanence to transcendence as well as in regards to the concept as construction in Schelling in relation to the Platonic Idea as generative (and pre-conceptual) pattern contra Deleuze (and Guattari). Schelling's concept is opposed to Deleuze's formulation as a virtual multiplicity ${ }^{2}$ since it is not the act of construction (dialectical or otherwise) and since one cannot rely on a ground without the horror of the previous urgrund (Schelling 1997, 122) one must begin to view reality as that which is the stoppage and simultaneously continuation, of processes, powers, and so forth.

Dynamism must precede materiality as Idea must precede concept due to the fact that, as Grant argues: "The a priori is nature. ... Unless there were a nature there would be no thinking. The prius of thinking is necessarily nature" (Brassier, Grant, Harman and Meillassoux 2007, 342) and "there's a necessary asymmetry, if you like, between thought and what precedes it, and it's this asymmetry which means that thought is always different from what precedes it and always at the same time requires that what precedes it as its necessary ground.” (ibid., 343)

Furthermore, Grant demonstrates that thought's (or any entity's) inability to capture its preconditions is an aspect of nature and not only thought. Schelling's suggestion that there is something prior to thought (nature as prius) as well as that the transcendental (the most extensive capacity of thought) is thoroughly naturalized as part of nature, have serious ramifications for the trajectory of philosophy and the possibility of realism as it relates to the being of potency.

Schelling's somewhat turgid discussion of being in The Grounding of Positive Philosophy demonstrates the contours of this trouble. Being is the potency to be but not in that it has not yet become the being that it already is: "Being, therefore, is immediately, just as much being as it is the capacity to be. Indeed, it is pure being, entirely and completely objective being, in which there is just as little of a capacity as there is something of a being." (Schelling 2007a, 143)

Matter (and/or being) is comprised of forces and is thereby non-conceptual due to both the limit of the concept and the dynamic exceeding matter or being as we know it as being (conceptual being). Schelling connects this difficult to the inability of philosophy to hold onto intermediary concepts. (Schelling 1997, 150) It is due to this difficulty that being is often not that which is but is not a thing, as well as matter which is dynamic yet cannot be explained solely by its initial primordial process. 
Furthermore, any necessity of being must necessarily be before necessity, before the demands of the conceptual, dynamics must allow for the conceptual, the conceptual cannot necessitate anything. (Schelling 2007a, 207) This pre-necessary necessity is the transcendent concept (devoid of anterior potency) opposed to the immanent concept. (ibid., 208) The transcendent is only that which transcends something else and is therefore only transcendence in, and about, thought. Concepts are "mere infinitudes" (Schelling 1984, 143) meaning that they are infinitely individual or infinitely finite. (ibid., 150) In opposition to this powers and potencies are that which describe the activity proper to being. The first primordial being (the transcendent absolute) self inhibits in order to generate a bifurcation thereby causing a succession of powers. (Schelling 1994a, 203)

This succession of powers does not seem to directly correspond to succession of things as appearance:

In Nature, therefore, the whole absolute is knowable, although appearing Nature produces only successively, and in (for us) endless development, what in true Nature, exists all at once and in an eternal fashion." (Schelling 1995, 272)

Nature is dynamic yet appears substantial as a result of nature being an inhibited infinity, absolute activity inhibited ad infinitum." (Schelling 2004, 15)

Against Deleuze, and in service of a non-substantial dynamism Schelling writes: "there is an end to all those absolute qualitative differences of matter which a false physics fixes and makes permanent in the so called basic substance: All matter is intrinsically one, by nature pure identity; all difference comes solely from the form and is therefore merely ideal and quantitative." (Schelling 1995, 137)
Immanence, which does not properly enter Schelling's vocabulary, is that what follows the self-inhibition of transcendence, following transcending its initial inhibition (where it leaves itself and the originary contingency or primary potency is left as nothing or no-thing) as attraction and contraction and becomes non-identical, it begins the series, or succession of things. (Schelling 1994, 114-116) For Schelling materialism fails as it is simply atomistic and cannot explain the genesis of intelligence (Schelling 1993, 57) without turning matter into something else (which Deleuze does but by turning materialism into a conceptual thinkability). Schelling utilizes the concept as that which is the thinkability of the Platonic Idea (Schelling 1995, 31) to utilize concept beyond this is only for the pleasure of the philosopher as Laruelle suggested above. The concept is only a small part of retransforming reality into ideality mimicking the unknown transition from ideality into reality. (Schelling 1966, 13) This model of genesis is Anti-Kantian and anti-Deleuzian.

Schelling dispatches with the Kantian categories of a priori and a posteri and secondly Schelling places the very function of subjecting or thinking in nature and not any subject as a formal gap or other form of aleatory structure. For Schelling nature performs the ontological and epistemological work thereby subordinating the ideal to the real in terms of genesis, or ontological, if not philosophical priority. The very status of this work, of the productivity of nature rewires the Kantian-Hegelian orientations of both immanence and transcendence as both become part of real nature and not ideal constructions. In the Grounding of Positive Philosophy Schelling critiques Kant's form of transcendence as an empty gesture, as a 
transcendence which is not transcendent to any particular thing. (Schelling 2007a, 208) For Schelling transcendence is when movement occurs from idea to existence or brings the real to the ideal. (Schelling 2004, 194)

Whereas for Schelling the materialist and idealist projects are separate the idealist project is always subordinate ontologically to the materialist project or the philosophy of nature. Schelling writes: "we require to know, not how such a Nature arose outside us, but how even the very idea of such a Nature has got into us; not merely how we have, say, arbitrarily generated it, but how and why it originally and necessarily underlies everything that our race has ever thought about Nature." (Schelling 1995, 41) Since the very idea is part of nature and nature is in us, then thinking as such is nature thinking through us attempting to think itself.

This thinking nature flirts with Platonism, as already suggested, as the idea no longer belongs to any particular engine of consciousness (human or otherwise) as ideas becoming living or merely a part of an always changing nature. (Schelling 1966, 116) Ideality then is, following Schelling, nature's attempt to become an object to itself, an endeavor which is always futile given the dynamism of nature and subsequently, of the idea.

Throughout his texts, Schelling constantly articulates the idea as something outside the limits of both logic and empiricism, presenting the idea as an infinite potentiality (ibid.,) where the thing is only the appearance of the idea (Schelling 1994a, 177) the idea is part of nature. (Schelling 1984, 12)
It should be argued then that thought is a force in itself that, as Grant puts it, "nature thinks" as the nature of thinking, and particularly philosophical thinking, is that of a mobility, knowing that this mobility is not contained in the notion but always referring to nature as substrate. (Schelling 2007a, 133 and Grant 2006, 17)

Or as Grant nicely puts it: "If being is necessarily indeterminate, then this indeterminacy must precede its determination, since the converse would entail that being is determinate in advance of its determination." (Grant 2009, 449)

Here Schelling begins to approach the machinc constructivism of Deleuze's atomized consciousness but we can see an attack on Deleuze's concept of conceptualization and his relation of immanence and transcendence. The very ground of material necessity, which is the focus of Schelling's Naturphilosophie, is the infinite potentiality of natural ideation, which is why transcendence, instead of marking the work of ideation from the ground of human phenomenality or reason, is the movement of these natural, unthinkable ideas, to existence, to discernible reality. This relation, and Deleuze's relation to the transcendental complicates the generative stance of the idea:

The transcendental cannot be "induced" or "traced" from the ordinary empirical forms of common sense. The being of the transcendentally sensible is that which can only and involuntarily be sensed ... Experience, then, being immanent to itself and not to an individualized subject, is thereby transcendent. (Mullarkey 2007, 14) 
As Mullarkey explains, Deleuze utilizes the transcendental as generative of experiences as his response to Hume is essentially in opposition to that of Kant's. That is, whereas Kant seeks a priori synthetic categories to explain the unity of apperception, Deleuze attempts to materialize or physicalize Hume; as Mullarkey writes, "So, by adopting the position that runs immanence and transcendence together by making immanence absolute, Deleuzian empiricism converges with materialism, finding in purely physical matter the conditions which generate the self, such that experience no longer needs a host in a (non-material) subject." (ibid., 14)

While this empiricism, as radical as it is, would seem to provide a realistic model (albeit one of deep access to the cosmos beyond thought) it, as Brassier argues, merely returns the world to an original and enchanted state where the world is automatically thinkable. (Brassier 2008, 28) The difference between concepts and objects is problematically flattened.

The problem of Deleuze, of his hyper philosophy of thinkable immanence is, again following Mullarkey, one that can be tied to the absence of the negative in his work. Without the negative, without points of epistemological limit or disruption, his materialism becomes a dense canitude, where everything seems permissible.

\section{Conclusion}

While much of Schelling's philosophy, as we have seen, is redolent of Deleuzian transcendental materialism, I maintain that the above described transcendental dynamism is, at its base, fundamentally different from Deleuze's system and stands as a better candidate for realism.

In Schelling's system there are grounds and powers as matter and substance are insufficient to the task of philosophy unless thought is to be integrated into those substances or matters. ${ }^{3}$ For Schelling, the first being, or first essence, must be contingency. (Schelling 1994, 116) Schelling also, similarly opposes yet integrates necessity and freedom. (Schelling 1966, 16) Yet this freedom cannot be reduced to human freedom or human will but works to connect the very anarchy of ground (Schelling 2007, 29) to nature as being in us and working through us.

While transcendental philosophy and a philosophy of nature are formally separate, or we might say operationally separate, they do not speak to two different worlds but only two different functional regimes; transcendental philosophy is the dynamics (and history of ) the mind. Grant writes: "the final phenomenal link between the act of thinking and the experience of the content of thought has been broken; to reinstate it is thereafter the function of transcendental philosophy, the only science with such a 'double series."' (Grant 2005, 54) This is not to say, pace Hegel, that the Naturphilosophie is obliterated by transcendental philosophy but that both transcendental idealism and naturphilosophical realism are subjectivities, sciences which are both rooted in nature but methodologically apart (Grant 2006, 174) adhering to both monist continuity and processual (or dispositional) heterogeneity.

Continuity in Schelling marks the necessity of a nonKantian transcendence in order to make nature as self-organizing subject possible as well as making 
idealism possible. Heterogeneity separates Schelling from Deleuze since for Schelling there is no difference-in-itself and there is an All but a non-all which expands and contacts outward. Continuity is a problem for Schelling where in Deleuze this is explained as the folding and unfolding of expression in the One substance while Schelling is unwilling to allow substance to do this degree of ontological work. The production of things in Schelling's transcendental dynamism is a progression of that very dynamism, as constructing an anti-thesis of forces, as self-inhibition towards non-dissolution. (Schelling 1995, 132)

Making energies, or activities the primary metaphysical building blocks (or building fluids more accurately) circumvents and shifts many problems of philosophizing about the world. The problems that arise from a Transcendental Dynamism, in a properly anti-correlationist sense, shifts the problems from being the world's to be being for us. Centrally, for our discussion here, thought becomes another kind of power (Grant 2009, 446) which behaves modally like other powers, potencies, processes and so forth. (Grant 2006, 202-203)

How does this relate to realism as opposed to materialism? While Grant's text mentions Schelling against historical materialism, (ibid., 46) against Fiechtean "vital materialism", (ibid., 100) while suggesting the possibility of an "absolute materialism," (ibid., 91) it remains unclear how exactly the term materialism relate to Schelling. Materialism, as Graham Harman has noted, becomes a kind of cover for idealism or, perhaps more specifically, it names a philosophy that wishes to remain between naïve idealism and naïve realism or empiricism, it wishes merely to remain intellectually immune. Grant, in his essay "Does Nature Stay What-it-is?" addresses the difficulties orbiting materialism as a philosophical endeavor. Grant notes that contemporary materialisms are, more often than not, without matter (Grant 2011, 70) and that dynamism is restricted to the region of logical space. While Grant discusses transcendental materialism in the above essay as Fichte negatively defines it and suggests it as a positive project, at least so far in it argues that nature constructs the I (and not vice versa as Fichte would have it) the term transcendental materialism remains wedded to both the above Deleuzian and Landian systems as well as the Hegelian-Lacanian works of Slavoj Žižek and Adrian Johnston.

I would propose that transcendental dynamism replace transcendental materialism for the sake of methodological distancing as well as conceptual clarity. ${ }^{4}$ In transcendental dynamism being is an original heterogeneity which produces identities/unities and continuities/differences in modal activities (forces, powers, processes, and procedures) in which materiality is secondary, as is sense and intelligence. ${ }^{5}$ Being, as the real, transcendentally shifts into different modes of being which provide different forms of epistemological access and from which different philosophies can be constructed. In this sense we can say Deleuze's philosophy operates from within sense (immanence being its intra-modality) whereas Schelling's (and Grant's) double series, attempts to show how idealism attempts to address the relation of sense and thought where the Naturphilosophie mines the shift from the real qua dynamism to the formation of materiality. 
Notes:

1. In each of these cases then I am utilizing transcendence and the transcendental in ways (at least partially) antithetical to Kant's usage. For Kant, the transcendental refers to "all knowledge which is occupied not so much with all objects in so far as this mode of knowledge is possible a priori" (Kant, Critique of Pure Reason, "Introduction," VII). Whereas Kant's transcendental is methodological, Schelling's transcendence/transcendental is metaphysical dynamic both with idealism and realism and across both.

2. For a different view, see Alberto Toscano's essay "Philosophy and the Experience of Construction" (Toscano 2004, 120-124).

3. It could be argued that this is what Bergson attempts throughout his oeuvre.

4. The term Transcendental Dynamism is not widely utilized and not in terms relevant to the discussion here. One notable exception is Xavier Zubri's utilization of the term (in Zubri 2003).

5. While numerous philosophies of dispositions, following in generally Aristotelian and anti-Humean strands, seek to construct a realist theory of powers, there remains a reluctance, in many if not all thinkers, to allow for powers all the way down instead relying on substance which, according to thinkers such as Andrew Bird, lead to quidditism or dualism.

\section{References:}

Brassier, Ray. 2001. Alien theory: The decline of materialism in the name of matter. Unpublished PhD diss. University of Warwick. http://wrap.warwick.ac.uk/4034 (accessed October 1, 2011).

2008. The expression of meaning in Deleuze's ontological proposition. Pli: The Warwick Journal of Philosophy 19.

Iain Hamilton Grant, Graham Harman, and Quentin Meillassoux. 2007. Speculative realism. Collapse: Philosophical Research and Development III: 307-449.

Grant, Iain Hamilton. 2005. On the eternal bond of philosophy and physics. Angelaki: Journal of the Theoretical Humanities 10,1: 43-59.
2006. Philosophies of nature after Schelling. London: Continuum. 2009. Prospects for post-Copernican dogmatism. Collapse: Philosophical Research and Development V: 413-414.

2011. Does nature stay what-it-is?: Dynamics and the antecendence criterion. In The speculative turn. Continental materialism and realism, eds. Levi Bryant, Nick Srnicek and Graham Harman, 66-83. Melbourne: re.press.

Kant, Immanuel. 1999. Critique of pure reason, ed. and trans. Paul Guyer and Allen W. Wood. Cambridge: Cambridge University Press.

Land, Nick. 1991. The thirst for annihilation: George Bataille and virulent nihilism. New York and London: Routledge.

2011. Fanged noumena: Collected writings 1987-2007. Falmouth: Urbanomic.

Laruelle, François. 2009. Response to Deleuze. Pli: The Warwick Journal of Philosophy 20.

Mullarkey, John. 2007. Post-continental philosophy: An outline. London: Continuum.

Schelling, F.W.J. 1966. On university studies, trans. E.S. Morgan. Columbus: Ohio University Press.

1984. Bruno: Or, on the natural and the divine principle of things, trans. Michael G. Vater. New York: SUNY Press.

1993. System of transcendental idealism, trans. Peter L. Heath. Virginia: University of Virginia Press.

. 1994. On the history of modern philosophy, trans. Andrew Bowie. New York: Cambridge University Press.

1994a. Idealism and the endgame of theory, trans. and ed. Thomas Pfau. Albany: SUNY Press.

1995. Ideas for a philosophy of nature, trans. Errol Harris and Peter Heath. Cambridge: Cambridge University Press.

2004. First outline of a system of the philosophy of nature, trans. Keith R. Peterson. Albany: SUNY Press.

2007. Philosophical investigations into the essence of human freedom, trans. Jeff Love and Johannes Schmidt. Albany: SUNY Press.

2007a. The grounding of positive philosophy, trans. Bruce Matthews. Albany: SUNY Press.

, and Slavoj Žižek. 1997. The abyss of freedom: Ages of the world, trans. Judith Norman. Ann Arbor: University of Michigan Press. 
Shaviro, Steven. 2009. Without criteria: Kant, Whitehead, Deleuze and aesthetics. New York: MIT Press.

Toscano, Alberto. 2004. Philosophy and the experience of construction. In The new Schelling, eds. Judith Norman and Alistair Welchman, 106-127. London: Continuum.

Zubri, Xavier. 2003. Dynamic structure of reality. Urbana: University of Illinois Press. 